\title{
Exploring the Use of Covid-19 as a New Pre-Text in Trump's Political Discourse
}

Dr. Grasiella K. Harb ${ }^{1 *}$ \& Dr. Youssef M. Serhan ${ }^{2}$

${ }^{1}$ Rafik Hariri University, Lebanon

?Islamic University of Lebanon, Lebanon

Corresponding Author: Dr. Grasiella K. Harb, E-mail: harbgk@rhu.edu.lb

ARTICLE INFO ABSTRACT

\section{Article History}

Received: August 02, 2020

Accepted: September 15, 2020

Volume: 2

Issue: 5

\section{KEYWORDS}

Critical Discourse Analysis

(CDA), Covid-19, Xenophobia, Hegemony, America vs China
With the rise in the spate of deaths in America and the failure of Trump in containing coronavirus pandemic, the president is losing his hopes of winning the coming presidential election. Amidst Trump's confusion, Covid-19 becomes a pre-text in his political rhetoric in an attempt to blame China for the pandemic, raise tension between U.S. and Beijing, and regain credibility from the public. Accordingly, the research paper aims to explore how Trump's outrageous language unveils his ideological hegemony and contributes to the spread of xenophobia towards China. A multidisciplinary qualitative analysis was adopted to analyze one of Trump's blunt political discourse. The analysis was based on Fairclough and Van Dijk's Critical Discourse Analysis (CDA) model, along with Halliday's Systemic Functional Linguistics (SFL) Model. The findings of the study are significant in raising the public's awareness of the manipulative social function of language in enhancing racism and inequality of power between nations.

\section{Introduction}

America's interest is not in resolving conflicts but in pulling its strings.

(adapted from Henry Kissinger, former American Secretary of State)

Going over the history of the United States in resolving conflicts, especially after World War II, we find that America did not seek any major role in finding resolutions unless it seized total control over things as Kissinger used to repeatedly describe. The United States creates conflicts in different regions to extend its power and control. Usually, this is accompanied with the creation of an enemy in order to raise fear in people and direct their attention away from the main issues. In fact, there are many examples on this policy. America started to lead the world for the purpose of fighting the communist bloc expansion. With the collapse of the bloc, there was a need for a new excuse for extending its global power. During George Bush presidency, a new frightening enemy was created under the name of Al-Qaida, which America would end through fighting terrorism. Another example is the creation of the Islamic State of Iraq and the Levant (ISIS) and the appearance of Islamophobia during Obama's leadership.

The importance of "the enemy industry" is in the advantages it offers, most significantly in silencing the American public or in getting the country out of internal conflicts and challenges. This enemy has always been a fundamental factor in the rhetoric of successive American administrations, so it is not surprising to find the current American president following in the footsteps of his predecessors. However, what Trump has been facing so far is different from what his ancestors had experienced. Despite his paranoid and narcissist personality as well as his continuous behavior as the sole source of power and the only rescuer, the president is heavily facing the dire consequences of flouting the virus. Trump and his administration underestimated Covid-19 and thought that they can contain it, only to discover their inability of dealing with the new enemy.

\section{K C AL-KINDI CENTER \\ $\boldsymbol{R}$ FOR RESEARCH AND DEVELOPMENT} Your gateway to world-class research
Published by Al-Kindi Center for Research and Development. Copyright (c) the author(s). This is an open access article under CC BY license (https://creativecommons.org/licenses/by/4.0/) 
This time the enemy is Covid-19, created for covering Trump's catastrophic failure in containing the virus. The attack on China comes at a time when it is seen crowding out US as a political leader due to its considerable economic power in the Middle East as well as in the African and European continents. Initially, America tried to use the virus crisis to harm China economically since the virus first appeared in the latter's land. This was clearly mentioned by Wilbur Russ, United States Secretary of Commerce, who saw economic benefits for his country with the transition of business and commerce from Asia to the north of the American continent. Later, Trump started his accusations and indictments against the Chinese government and the Chinese companies for the purpose of demonizing China and its actions towards the virus as well as its economic, political, and security actions.

Thus, after the appearance of the virus, Covid-19 became a pre-text in Trump's political rhetoric. Accordingly, the aim of the research study is to analyze the political and hegemonic function of language in Trump's public announcements. The paper presents a close analysis of the discursive patterns that reveal how Trump utilized the virus for enhancing xenophobia and stripping a whole race off their dignity and morality. "We cannot talk about an issue if we cannot identify it... It is only through a close analysis of the language that we can uncover the discursive patterns that contribute to such dangerous ideologies," (Fairclough, 2001, p.233). Hence, the paper raises the awareness to how language can manipulate the public's mind with dominant values and self-serving ideologies and contribute to the domination of those who do not share the same values.

The following part describes the theoretical framework that underpins the exploratory analysis of the study.

\section{Literature Review}

Critical Discourse Analysis (CDA) is conducted to unveil how language forms and sustains asymmetric power relations. Among its leading scholars are Norman Fairclough and Teun Van Dijk.

\subsection{Critical Discourse Analysis and Fairclough's Model}

Critical analysis interprets and explains areas of social life that help analysts identify the causes behind social wrongs and produce knowledge to righten or mitigate them if right conditions were available to do so. Analysts' interpretation includes not only people who act in certain social circumstances but also those who seek to govern and regulate those people, including political leaders and managers (Fariclough, 2010). CDA is based on a rhetorically-oriented analysis for the discursive practices and conventions used by these authority representatives to transform societies into different directions. Hence, their language is the primary medium of constructing identities, portraying ideology, and creating, transferring or retaining power.

Fairclough (2010) introduces a tripartite model for analyzing ideology and power within the discourse. The framework explores the overlaps between language, institutional practices, and social and power structures. The model analyzes the meaningmaking process across a three-dimensional-level analysis: description, interpretation, and explanation. The three dimensions are described below:

1. Description of the text: the first step of discourse analysis is to study the linguistic features of a text including phonology, word choice, grammar and sentence structure, semantics as well as textual organization and coherence. For Fairclough, textual analysis unveils the cognition and representation of the world and social interaction. Hence, it is linked with the analysis of language which people use in their everyday practices. However, it is insufficient because it does not show the relation between the text and the social and power structures.

2. Interpretation: the second dimension is related to the interpretation of the meaning of the text. It is mainly concerned with the way people produce the discourse, interpret, and transform it. It unveils the cognitive aspect which people rely on as well as their values, beliefs, and assumptions when producing and consuming discursive practices. "Discursive practices may have major ideological effects... they can help produce and reproduce unequal power relations between social classes, women and men, and ethnic groups through the ways in which they represent things and position people (Fairclough, 2011, p.358).

3. Explanation: The third dimension focuses on the social impact and social practices that result from receiving and interpreting the discursive practices. For Fairclough (2010), it is the critical aspect of CDA that analyzes the flaws of the society and institutions and compares them to how they should be in reality (negative and positive critique). The dimension heavily focuses on power relation, inequality, discrimination, and other gaps between societies and aims to bring about changes. This is why it is knotted to the historical, cultural, and social framework of the discourse. Hence, the explanation level unveils the ideology of people and the dialectical relations between language and power. 
Complementary to Faiclough's analysis of the dialectical relationship between language, ideology, and power is Van Dijk's sociocognitive analysis of the discourse. The analysis is primarily concerned with the way language is used to enact, reproduce, or resist forms of power abuse, hegemony, and inequality (Van Dijk, 2009). The following theme presents a description of Dijk's approach.

\subsection{Critical Discourse Analysis and Van Dijk's Model}

Van Dijk explains that dominating institutions use their discourse as a control mind to dominate the less powerful. This mental control is practiced not only through censured information conveyed to the dominated but also through the manner in which the information is relayed whereby the speakers put themselves either equal to the listeners or superior/inferior to them. In addition, the whole discourse context such as the communicative event and its goal, place, time, and type of participants involved plays a role in the mental control process. Hence, it is not enough to study the linguistic features of the discourse; it is crucial to relate such features to the elements of the discourse context. Then, the explicit or implicit ideology and hegemony can be formulated. Dijk adds that most research on ideological discourse often reflects the following ideological square:

1- Emphasize our good things

3- De-emphasize our bad things

2- Emphasize their bad things

4- De-emphasize their good things

(2004, p.18)

Van Dijk's (2004) socio-cognitive approach is based on two levels of discourse analysis described below:

1- Macrostructure of the text: in the macrostructure of a text, determining the thematic structure is essential to reflect power and inequality between groups. Deducing the theme helps convey the intention and message of the speakers as well as what they want from their audience. The theme is usually related to the topic of the discourse and reflects the dominant concept of the speaker. For a better understanding of the theme and its implicature, the analyst should take the social context into consideration. For example, during Trump's election campaign, regaining power was a dominant theme for the vitality it represents for Americans socially, economically, and politically. Trump as the chair of The Trump Organization and his qualification in doing businesses gives him credibility to gain what Nye (1990) describes as soft power. "Soft power is the ability to create a center of attention of people to one side without compulsion, and it has the capacity to persuade others to do what he wants (as cited in Rachman \& Yunianti, 2017).

2- Microstructure of the text: The microstructure of the text is related to the linguistic features (syntax style, semantic style, rhetoric style) which reflect the pragmatic properties of the discourse in terms of the speakers' intention, mood, emotions, and opinions about events. This is in addition to the attribution forms such as positive self-presentation, character profiling, and direct and indirect negative evaluations and perception about others. For instance, in Trump's rhetoric, there is a continuous message of assertiveness and power to the audience. America was a winner in the past but has become weak because of previous administrations who have "dumped" the country in a mess and strengthened the "others". There is always the use of pattern Us vs Them with frequent blunt phrases to revolt against the hegemonic order and bring power back to the Americans (Pearce, 2018; Quinonez, 2018).

The two models above play a fundamental role in the critical discourse analysis of political rhetoric; however, with Halliday's Systemic Functional Linguistics (SFL) theory, the social semiotic function of language becomes more "concrete". The following theme gives a descriptive explanation of how critical discourse analysis uses SFL as a fundamental tool to show the relationship between language, society and power.

\subsection{Halliday's Systemic Functional Linguistics (SFL) Model}

Systemic functional linguistics views language with a social semiotic function. In the course of communication, language is viewed as a system of meaning which supplies the speaker with a variety of grammatical choices (Halliday \& Matthiessen, 2015). The word choice and its embodiment in the structure of the clause reflect the intended meaning of the user. "Systemic functional linguistics view language as a social semiotic in which semogenesis (meaning-making) is construed by context of situation which in turn is construed by culture," (Cordeiro, 2018, p.217).

Halliday (1994) assigned three meta-functions for language: 1) experiential meta-function (represents the human experience and mainly focuses on the clause as a representation of the speaker's experience), 2) the interpersonal meta-function (reflects the personal and social relationship between the user and the audience/listener and focuses on the clause as a reflection of exchange), 3) the textual meta-function (reflects the coherent discursive flow of a unified text and focuses on the clause as a message. The current study focuses only on the experiential and interpersonal meta-function since the aim is to explore Trump's construction of reality and his embedded ideology. 
The experiential meta-function is mainly based on the transitivity system that describes the whole clause. According to this system, the clause reflects the experience in terms of what is happening, what is done, felt, said, and sensed (as cited in Wang, 2010). Accordingly, the structure of the clause is studied in terms of the actor/agent, process, goal, and circumstances.

According to transitivity analysis, the participant's role is determined based on the six types of processes described below:

1- Material Process: It reflects an action verb done by the Actor (main subject), and the Goal is involved as the direct object of the action (e.g. give, raid, steal).

2- Mental Process: It reflects a perception, affect, or cognition. It involves two participants identified as Senser and Phenomenon (e.g. think, know, hope).

3- Relational Process: It is classified into two types: Attributive and Identifying. The former applies attributes on the participant or carrier (e.g. He is a winner), whereas the latter places a value or a label for the participant (e.g. He has an expensive watch).

4- Verbal Process: It involves verbs of actual speech commonly used for exchanging information (e.g. say, ask, describe)

5- Behavioral Process: It reflects physiological or psychological behavior of a participant (e.g. breathe, smile, cough).

6- Existential Process: It represents something as existing or happening (e.g. There is a fishy thing happening).

Trump's rhetoric often includes clauses with experiential, relational, and expressive discursive patterns to point out different social actor roles whether in terms of a savior agent or a destructive one (Mohammad \& Jawid, 2017; Salayo, 2020; Sulistyo \& Khristianto, 2017).

Moreover, the interpersonal meta-function reflects the social relationship between the speaker and the hearer. The modality system often reflects this relationship and helps in inferring the speaker's opinion and judgment towards the topic and the audience. So, the system is significant in establishing the identity of the speaker (Simpson, 2004). Modality can be realized through modal adjuncts, pronouns, adjectives, tenses, and mood of the sentence. They reflect the speaker's role, attitude, social stance, and assigned role to the audience. For instance, the inequality of power between Us and Them and the need to make the United States stronger again is reflected in Trump's modality patterns exemplified by the use of exclusive and inclusive We and Our. The function of these pronouns is to build a close interpersonal relation with the audience and win their support (Bonilla, 2020; Mohammad \& Jawad, 2017). On one hand, the We is portrayed negatively to highlight the juxtaposition between the American's misfortunes and the prosperity of Them. On the other hand, the inclusive use of We holds a strong determination of bringing power and glory to all Americans.

Based on the above theoretical framework, the research question that guides the present research paper is: How does Trump's political discourse unveil his exploitation of Covid-19 and project his ideological hegemony at the micro and macro level?

\section{Methodology}

The present research paper is a qualitative multidisciplinary study. It adopts Fairclough and Van Dijk's critical discourse analysis model. It also employs Halliday's Systemic Functional Linguistics Model as a tool for the linguistic analysis of the discursive patterns.

Purposive sampling was adopted in selecting the discourse for analysis. Data was collected from Donald Trump's Press Announcement about China in the Rose Garden delivered on May 29, 2020. The political rhetoric was chosen on the basis of its language and themes that reflect the aim of the study. The press conference was held as tensions between U.S. and China escalated. Trump outrageously blamed China for the spread of the coronavirus pandemic. Relation between the two countries was further strained as China defied Washington and imposed a national security legislation on Hong Kong. Thus, America viewed Hong Kong as no more autonomous from China. On another hand, the announcement is done only six months before the new presidential election, which Trump seeks to win.

The speech is collected from https://factba.se/transcript/donald-trump-remarks-press-announcement-china-who-may-292020 (see Appendix 1). Clauses only related to the objective of the study were selected.

\section{Results and Discussion}

The analysis of Trump's announcement at the macro and micro level revealed two main themes described below along with a description to the linguistic features of the text. 


\subsection{China: A Growing Threat to the Americans}

Trump attempts to influence the public through a biased social representation of China. He uses his authority to control the audience's mind with his negative depiction of China to appeal to their pathos and provoke their anger and revolt. The following lines reflect Trump's mental control process by emphasizing China's "bad things" and America's "good things" as per Van Dijk's description (2004):

2- For decades, they have ripped off the United States like no one has ever done before. China raided our factories, offshored our jobs, gutted our industries, stole our intellectual property, and violated their commitments under the World Trade Organization.

4- China has also unlawfully claimed territory in the Pacific Ocean ...

5- The Chinese government has continually violated its promises to us and so many other nations.

6- China's cover-up of the Wuhan virus allowed the disease to spread all over the world, instigating a global pandemic that has cost more than 100,000 American lives and over a million lives worldwide.

7- Chinese officials ignored their reporting obligations to the World Health Organization and pressured the World Health Organization to mislead the world when the virus was first discovered by Chinese authorities.

14- For years, the government of China has conducted illicit espionage to steal our industrial secrets, of which there are many.

16- Investment firms should not be subjecting their clients to the hidden and undue risks associated with financing Chinese companies that do not play by the same rules.

18- This week, China unilaterally imposed control over Hong Kong security.

The above lines uncover Trump's overt ideology by representing China in an offensive and provocative language. The clauses reflect a negative appraisement to the other. Trump places China in the agentive position and uses the transitive material process to project its power and continuous threat. Table 1 below shows the transitivity pattern analysis and clarifies the experiential meaning that Trump was trying to create in his discourse.

\begin{tabular}{|c|c|c|}
\hline Actor & Process & Goal \\
\hline China & $\begin{array}{l}\text { raided, gutted, stole, violated, } \\
\text { claim, threaten, cover-up }\end{array}$ & $\begin{array}{l}\text { our factories, our industries, our } \\
\text { intellectual property, their } \\
\text { commitments, territory, freedom, } \\
\text { Wuhan virus }\end{array}$ \\
\hline They & $\begin{array}{l}\text { ripped of, refused to act, failed to } \\
\text { make }\end{array}$ & Unites States, $\varnothing$, the requested \\
\hline Chinese Government & violated, imposed & $\begin{array}{l}\text { promises to us, control over Hong } \\
\text { Kong }\end{array}$ \\
\hline Chinese Officials & ignored, pressured & $\begin{array}{l}\text { reporting obligations to the WHO, } \\
\text { the WHO }\end{array}$ \\
\hline Chinese Companies & do not play by & the same rules \\
\hline
\end{tabular}

Table 1. Transitivity Analysis: Theme 1

The transitivity analysis in Table 1 reflects an asymmetric power relation in which China is mainly taking the actor role and America the subjugated one (goal). The material process shared between the role of the actor and the role of the goal is based on negatively connoted action verbs such as "raided", "stole", "violated", "ripped off", "cover-up". China is represented by its negative, immoral and illegitimate actions, and America is portrayed as the victim playing a subservient role in front of the growing threat of China (our factories, our property, promises to us, etc...). Furthermore, the use of parallelism such as in line 2: "For decades, they have ripped off the United States like no one has ever done before. China raided our factories, offshored our jobs, gutted our industries, stole our intellectual property, and violated their commitments under the World Trade Organization" and the use of boosting adverbs such as "unlawfully: line 4", "continually: line 5", "unilaterally: line 18" bring out Trump's attitude towards China and project his attempt to heighten the public's emotion by reflecting his concern about the disproportionate power between "Us" and "Them". 
Moreover, the use of the past tense in the representation of China's practice and the use of time deixis such as "for decades: line 2", "for years: line 14", "this week: line 18" imply the failure of the previous establishments in standing against China. The present perfect, on the other hand, indicates that China is still continuing with its breaches and violations, and it's high time America stood in front of its dominance, which leads us to theme 2 analysis.

Trump's blame is not only limited to the previous American governments. He continues to veil his failure by implying a sense of conspiracy about Covid-19 to grow hatred and fear towards China such as in the lines below:

4- China has also unlawfully claimed territory in the Pacific Ocean, threatening freedom of navigation and international trade. And they broke their word to the world on ensuring the autonomy of Hong Kong.

11- The world needs answers from China on the virus. We must have transparency. Why is it that China shut off infected people from Wuhan to all other parts of China? It went nowhere else. It didn't go to Beijing; it went nowhere else. But allowed them to freely travel throughout the world, including Europe and the United States.

12- The death and destruction caused by this is incalculable. We must have answers not only for us but for the rest of the world.

13- This pandemic has underscored the crucial importance of building up America's economic independence, reshoring our critical supply chains and protecting America's scientific and technological advances.

16-Americans are entitled to fairness and transparency.

The above extracted accusations show Trump's depiction of China as a country that does not comply with its international obligations and commitments. First, he accused the country of annexing territories illegally from the Pacific Ocean, implying an act that would jeopardize the peace and security of international navigation and trade. Another frightening implicature is that China is cheating not only the Americans but the whole international community by not submitting true facts about the virus, which have resulted in the death of a great number of Americans, let alone the continuous growing number of infection cases: "The world needs answers from China on the virus. We must have transparency", "We must have answers not only for us but for the rest of the world." Also, in the above lines, Trump appeals to the pathos of the audience using the transitive mental process pattern. The mental process verbs "needs answers: line 11" "must have transparency: line 11", "must have answers: line 12" "entitled to fairness and transparency: line 16" signify the manipulative function of power in controlling the audience's mind. By "We" as the main actor, Trump wants to co-opt the public into his team. He wants to move America from the object of exploitation (goal role) to the agent of power and control (actor of the sentence). The inclusive pronouns "we", "our", and "us" are ideologically positioned to signify the unity between the speaker and the audience and the need for joint efforts and support. Using an interpersonal functional language, Trump identifies himself with the public and shows care about their welfare. Hence, utilizing inclusive pronouns is an element of persuasion to win favor with the Americans and divert their attention from his continuously failing rescuing attempts.

Then, Trump suddenly shifts from holding China responsible for the pandemic to accusing the country of violating its commitments regarding the autonomy of Hong Kong, not respecting by that human rights. The extract lines below present the accusation.

18- This week, China unilaterally imposed control over Hong Kong security.

20- This is a tragedy for the people of Hong Kong, the people of China, and indeed the people of the world.

21-... Hong Kong is no longer sufficiently autonomous to warrant the special treatment that we have afforded the territory since the handover.

22- China has replaced its promised formula of "one country, two systems" with "one country, one system."

The lack of coherence between the patterns of accusation reflects the disarray condition of the American president along with the confusion state of his government in saving the country and containing the virus. Trump tries by all means to save his distorted image as a leader who lost control over Covid-19. He accuses China of jeopardizing the security, economy, and technology of America. Then, he incoherently shifts to China being suspected of organizing a conspiracy about the virus against the world with the help of the World Health Organization. Also disjointedly, he accuses China of illegally breaching all its commitment and respect to human rights. Doing so, Trump restores broken ties with China. On another note, the confusion 
and incoherence in Trump's rhetoric and thoughts come at a crucial point, few months before the presidential election. Trump does not want his failure with the pandemic to disrupt his election campaign.

In conclusion, Trump's language and blunt lexical choice reinforce the ideology of in-group/out-group. The contrast of we as morally good and they as morally suspect serves in making the audience reasonably accept the president's fully-grounded reformation plans. These plans and the way they are communicated are analyzed in the following theme.

\subsection{Trump the Savior: The Ideology of Personality Profiling}

Failing to curb the accelerated spread of the virus, Trump decided to generate further tension with China. He started to intensify his embedded and indirect messages, calling for national unity on one hand and implying vengeful acts and electoral motives on the other hand. These implied calls are communicated through a rhetoric dominated by the ideology of personality profiling and self-glorification. The following extracted lines reveal how Trump presents himself as a saving president uniting all the Americans against their war with China, the main source of the virus.

1. I'm here today to talk about our relationship with China and several new measures to protect American security and prosperity

3. But I never solely blamed China for this.... my administration negotiated and fought for what was right.

8. They strongly recommended against me doing the early ban from China, but I did it anyway and was proven to be 100 percent correct.

14. ... Today, I will issue a proclamation to better secure our nation's vital university research and to suspend the entry of certain foreign nationals from China who we have identified as potential security risks.

15. I am also taking action to protect the integrity of America's financial system -- by far, the best in the world. I am instructing my Presidential Working Group on Financial Markets to study the differing practices of Chinese companies listed on the U.S. financial markets, with the goal of protecting American investors.

23. Therefore, I am directing my administration to begin the process of eliminating policy exemptions that give Hong Kong different and special treatment.

24. My announcement today will affect the full range of agreements we have with Hong Kong, from our extradition treaty to our export controls on dual-use technologies and more, with few exceptions.

29. In every decision, I will continue to proudly defend and protect the workers, families, and citizens of the United States of America.

The above lines reflect Trump's aim of building a credible ethos that appeals to the audience's logic and emotions (logos and pathos). He uses different ways of rhetorical self-projection to depict himself as the "savior" of the American community who will revive the glory and economic prosperity of his country. His discourse is dominated with a positive self-representation reflected through self-mentions and self-referential terms such as I, my administration, my announcement, the United Sates. Such rhetoric style takes the propaganda form. To be more specific, the repetition of the prenominal / serves in isolating Trump from others and in foregrounding his personality to the public, which is a means of public mental control into believing his assertions.

Moreover, the bold parts in the selected extracts are all examples of transitivity patterns with material process. All clauses are in the active voice and emphasize one main action or achievement such as "I never solely blamed: line 3", "I did it anyway: line 8" "I will issue a proclamation: line 14". Highlighting one specific action per clause helps the audience follow the achievements of the speaker. Also, the active voice with the use of " $I$ " as the policy maker helps the president arouse the public's confidence in him and his government. It reflects the figure of the wise leader who best knows what serves the interest of his country and the well-being of his people. Adding to that, booster expressions such as "they strongly recommended me doing the early ban from China, but I did it anyway and was proven to be 100 percent correct," draw contradicting images for the purpose of emphasizing Trump's sound leadership in contrast to others. Hence, with Trump occupying the position of the main doer, he portrays himself as action oriented. America will become strong again, and this is through rational actions and not mere thoughts and promises which the previous administrations used to give to its people. Expressing these actions in the present progressive and the future tense such as in "I will issue, I am taking action to protect, I am instructing /directing ..." implies a positive outlook and a new vision lead by a great, determined, and wise president. 
Inclusive pronouns collocated with the modal "will" also appear frequently in the reformation-plan part of the announcement. The lines below are few examples on how Trump draws the public into the power of his team, who is "vigorously" working to bridge the power gap between America and China:

5. The United States wants an open and constructive relationship with China, but achieving that relationship requires us to vigorously defend our national interests.

10. We have detailed the reforms that it must make and engage with them directly, but they have refused to act. Because they have failed to make the requested and greatly needed reforms, we will be today terminating our relationship with the World Health Organization and redirecting those funds to other worldwide and deserving, urgent, global public health needs.

17. Several of the most significant actions we're taking pertain to the deeply troubling situations unfolding in Hong Kong.

25. We will be revising the State Department's travel advisory for Hong Kong to reflect the increased danger of surveillance and punishment by the Chinese state security apparatus.

26. We will take action to revoke Hong Kong's preferential treatment as a separate customs and travel territory from the rest of China.

27.The United States will also take necessary steps to sanction PRC and Hong Kong officials directly or indirectly involved in eroding Hong Kong's autonomy and -- just if you take a look, smothering -- absolutely smothering Hong Kong's freedom. Our actions will be strong. Our actions will be meaningful.

The lines above reflect an ideological use of the modal "will". The reiteration of "we will/ our ... will" shows Trump's determination to make We more powerful than They. The repetition also shows a high level of commitment and certainty to get permanent solutions for conflicts with China. His assertive "will" is a mind control tool that enhances his credibility in the eyes of the public. The use of "will" rather than "shall" distinguishes Trump as a president with a powerful and united team, unlike previous ordinary politicians and administrations.

To conclude, the second theme analysis shows a sample of the egocentric language and character profiling propaganda that usually dominates Trump's rhetoric. He is always right in every action he takes and, thus, does not hesitate to berate predecessor presidents and administrations. He has come to fix previous mistakes and make the necessary amendments that best serve the American people. With this mentality, he proceeds with veiling his failure in dealing with Covid-19. He comes out with a list of decisions that protects the overall United States economy, "-by far, the best in the world." By this, he implies that the economy of China is and should remain behind in terms of power. One of the ways to do so is to reconsider relations with Hong Kong. At the end, he finishes his rhetoric with his unwillingness to negotiate with the Chinese president; a stance which reflects his egocentric and moody personality.

\section{Conclusion}

Trump is facing continuous unfolding crises and serious emerging issues. His country is grappling with an unprecedented pandemic, which had disastrous impact on the global economy. The American economy is what Trump is building hopes on to run for a second presidential term. However, recent events have exposed the president's failure in curbing Covid-19. The rapid spread of the virus unveiled the uncertainty and confusion of Trump and his administration. He had announced at the beginning of the crisis the ability of his country in containing the virus only to discover his underestimation of the pandemic and impotence in front of the increasing rate of infections and the spate of deaths. Seeking a justification for his failure, Trump provoked tension with China. He accused the Chinese of planning a conspiracy, with the involvement of the World Health Organization, and lying to the whole world with reports on Covid-19. Adding to that, he went to extremes with his condescending language and haughty personality, confirming his unwillingness of communicating with president Xi Jinping and threatening to sever ties between Washington and Beijing, hence restoring strained relationships between the two countries. It is also worth noting that political analysts read Trump's accusation to China as his ultimate trump card at the end of his presidency. Through his hostile rhetoric, Trump is seeking the trust of the American voters, especially that his speech found an echo in many Republic districts.

Moreover, the analysis of the discursive patterns in Trump's public announcement best exemplifies the president's ideological hegemony and spread of xenophobia during Covid-19 crisis. The study explored how his language positions various actors with different functions to signify asymmetrical power relations between America and China. Transitivity and modality system analysis revealed Trump's presuppositions and judgments about the relationship with China. This is in addition to his manipulation of the public's ethos and pathos in an attempt to gain credibility and support. 
So, will the current American administration accomplish its goals within all its confusion and uncertainty? Will the American investment in creating enemies and provoking conflicts remain a fruitful strategy, particularly given the current confusion in Syria and Yemen? Does the American administration need to reconsider a more realistic political rhetoric and move towards real rather than superficial resolutions that only serve its interest? To respond to these questions, a CDA for one political rhetoric for Trump is not enough. The whole world is held hostage to the president's moody temper and continuous disarray in reading his enemies and allies. Hence, we need more research studies that carefully analyze the continuous unfolding events and clarify what is next on the horizon.

\section{References}

[1] Bonilla, J.F. (2020). Critical discourse analysis of Trump across time. Sustainable Miltilingualism, 16, 1-20.

[2] Cordeiro, C.M. (2018). Using systemic functional linguistics as method in identifying semogenic strategies in intercultural communication: A study of the collocation of "time" and "different" by Swedish managers with international management experiences. Journal of Intercultural Communication Research, 47(3), 207-225.

[3] Fairclough, N. (2001). Language and power (2nd ed.). London: Longman/Pearson.

[4] Fairclough, N. (2010). Critical Discourse Analysis. The Critical Study of Language. United Kingdom: Edinburgh Gate.

[5] Fairclough, N. (2011). Critical Discourse Analysis. The Critical Study of Language (2nd ed.). London \& New York: Routledge.

[6] Halliday, M.A.K. (1994). Introduction to Functional Grammar (2nd ed.). London: Edward Arnold.

[7] Halliday, M.A.K., \& Matthiessen, M.I.M. (2015). Halliday's Introduction to Functional Grammar (4 ${ }^{\text {th }}$ ed.). New York: Routledge.

[8] Mohammadi, M., \& Jawadi, J. (2017). A critical discourse analysis of Donald Trump's language use in US presidential campaign, 2016. International Journal of Applied Linguistics \& English Literature, 6 (5), 1-10.

[9] Pearce, J. (2018). A politics of the people: Comparing the use of populist discourse in the 2016 US presidential election. LSE Undergraduate Political Review, 1, 22-57. Doi: https://doi.org/10.21953/Ise.nqq3eycr36ij.

[10] Quinonez, E. S. (2018). (Un)welcome to America: A critical discourse analysis of anti-immagrant rhetoric in Trump's speeches and conservative mainstream media. (Master's thesis, California State University, San Bernardino). Retrieved from https://scholarworks.lib.csusb.edu/etd/635.

[11] Rachman, A., \& Yunianti, S. (2017). Critical discourse analysis in Donald Trump presidential campaign to win American's heart. TELL Journal, 5(2), 8-17.

[12] Salayo, J.D. (2020). Women's right, a call for life: A critical discourse analysis of pres. Donald Trump's speech for the 2020 march for life. Journal of English Education and Linguistics Studies, 7(1), 115-135.

[13] Simpson, P. (2004). Stylistics: A Resource Book for Students. London \& New York: Routledge.

[14] Sulistyo, B.A., \& Khristianto, K. (2017). Political discourse analysis on Trump's ideology. Jurnal Sains Social dan Humaniora, 1(1), 1-12. Doi: 10.30595/jssh.v1i1.1035

[15] Van Dijk, T.A. (2004). Politics, Ideology and Discourse. Retrieved from http://www.discourse-in-society.org/teun.html.

[16] Van Dijk, T.A. (2009). Society and Discourse: How Social Contexts Influence Text and Talk. New York: Cambridge University Press.

[17] Wang, J. (2010). A critical discourse analysis of Barack Obama's speeches. Journal of Language Teaching and Research, 1(3), 254-261. Doi: $10.4304 /$ jtr.1.3.254-261.

\section{Appendix}

Donald Trump Press Announcement about China in the Rose Garden - May 29, 2020 
1- Thank you very much. Good afternoon. Thank you. I'm here today to talk about our relationship with China and several new measures to protect American security and prosperity.

2- China's pattern of misconduct is well known. For decades, they have ripped off the United States like no one has ever done before. Hundreds of billions of dollars a year were lost dealing with China, especially over the years during the prior administration. China raided our factories, offshored our jobs, gutted our industries, stole our intellectual property, and violated their commitments under the World Trade Organization. To make matters worse, they are considered a developing nation getting all sorts of benefits that others, including the United States, are not entitled to.

3- But I never solely blamed China for this. They were able to get away with a theft like no one was able to get away with before because of past politicians and, frankly, past presidents. But unlike those who came before, my administration negotiated and fought for what was right. It's called: fair and reciprocal treatment.

4- China has also unlawfully claimed territory in the Pacific Ocean, threatening freedom of navigation and international trade. And they broke their word to the world on ensuring the autonomy of Hong Kong.

5- The United States wants an open and constructive relationship with China, but achieving that relationship requires us to vigorously defend our national interests. The Chinese government has continually violated its promises to us and so many other nations.

6- These plain facts cannot be overlooked or swept aside. The world is now suffering as a result of the malfeasance of the Chinese government. China's cover-up of the Wuhan virus allowed the disease to spread all over the world, instigating a global pandemic that has cost more than 100,000 American lives and over a million lives worldwide.

7- Chinese officials ignored their reporting obligations to the World Health Organization and pressured the World Health Organization to mislead the world when the virus was first discovered by Chinese authorities.

8- Countless lives have been taken, and profound economic hardship has been inflicted all around the globe. They strongly recommended against me doing the early ban from China, but I did it anyway and was proven to be 100 percent correct.

9- China has total control over the World Health Organization, despite only paying \$40 million per year compared to what the United States has been paying, which is approximately $\$ 450$ million a year.

10- We have detailed the reforms that it must make and engage with them directly, but they have refused to act. Because they have failed to make the requested and greatly needed reforms, we will be today terminating our relationship with the World Health Organization and redirecting those funds to other worldwide and deserving, urgent, global public health needs.

11- The world needs answers from China on the virus. We must have transparency. Why is it that China shut off infected people from Wuhan to all other parts of China? It went nowhere else. It didn't go to Beijing; it went nowhere else. But allowed them to freely travel throughout the world, including Europe and the United States.

12- The death and destruction caused by this is incalculable. We must have answers not only for us but for the rest of the world.

13- This pandemic has underscored the crucial importance of building up America's economic independence, reshoring our critical supply chains and protecting America's scientific and technological advances.

14- For years, the government of China has conducted illicit espionage to steal our industrial secrets, of which there are many. Today, I will issue a proclamation to better secure our nation's vital university research and to suspend the entry of certain foreign nationals from China who we have identified as potential security risks.

15- I am also taking action to protect the integrity of America's financial system -- by far, the best in the world. I am instructing my Presidential Working Group on Financial Markets to study the differing practices of Chinese companies listed on the U.S. financial markets, with the goal of protecting American investors.

16- Investment firms should not be subjecting their clients to the hidden and undue risks associated with financing Chinese companies that do not play by the same rules. Americans are entitled to fairness and transparency.

17- Several of the most significant actions we're taking pertain to the deeply troubling situations unfolding in Hong Kong.

18- This week, China unilaterally imposed control over Hong Kong security. This was a plain violation of Beijing's treaty obligations with the United Kingdom in the Declaration of 1984 and explicit provisions of Hong Kong's Basic Law. It has 27 years to go.

19- The Chinese government's move against Hong Kong is the latest in a series of measures that are diminishing the city's longstanding and very proud status.

20- This is a tragedy for the people of Hong Kong, the people of China, and indeed the people of the world. China claims it is protecting national security. But the truth is that Hong Kong was secure and prosperous as a free society. Beijing's 
decision reverses all of that. It extends the reach of China's invasive state security apparatus into what was formerly a bastion of liberty.

21- China's latest incursion, along with other recent developments that degraded the territory's freedoms, makes clear that Hong Kong is no longer sufficiently autonomous to warrant the special treatment that we have afforded the territory since the handover.

22- China has replaced its promised formula of "one country, two systems" with "one country, one system.

23- Therefore, I am directing my administration to begin the process of eliminating policy exemptions that give Hong Kong different and special treatment.

24- My announcement today will affect the full range of agreements we have with Hong Kong, from our extradition treaty to our export controls on dual-use technologies and more, with few exceptions.

25- We will be revising the State Department's travel advisory for Hong Kong to reflect the increased danger of surveillance and punishment by the Chinese state security apparatus.

26- We will take action to revoke Hong Kong's preferential treatment as a separate customs and travel territory from the rest of China.

27- The United States will also take necessary steps to sanction PRC and Hong Kong officials directly or indirectly involved in eroding Hong Kong's autonomy and -- just if you take a look, smothering -- absolutely smothering Hong Kong's freedom. Our actions will be strong. Our actions will be meaningful.

28- More than two decades ago, on a rainy night in 1997, British soldiers lowered the Union Flag, and Chinese soldiers raised the Chinese flag in Hong Kong. The people of Hong Kong felt simultaneously proud of their Chinese heritage and their unique Hong Kong identity. The people of Hong Kong hoped that in the years and decades to come, China would increasingly come to resemble its most radiant and dynamic city. The rest of the world was electrified by a sense of optimism that Hong Kong was a glimpse into China's future -- not that Hong Kong would grow into a reflection of China's past.

29- In every decision, I will continue to proudly defend and protect the workers, families, and citizens of the United States of America. Thank you very much. Thank you.

Tables

\begin{tabular}{|l|l|l|}
\hline Actor & Process & Goal \\
\hline China & $\begin{array}{l}\text { raided, gutted, stole, violated, } \\
\text { claim, threaten, cover-up }\end{array}$ & $\begin{array}{l}\text { our factories, our industries, our } \\
\text { intellectual property, their } \\
\text { commitments, territory, freedom, } \\
\text { Wuhan virus }\end{array}$ \\
\hline They & $\begin{array}{l}\text { ripped of, refused to act, failed to } \\
\text { make }\end{array}$ & Unites States, $\varnothing$, the requested \\
\hline Chinese Government & violated, imposed & $\begin{array}{l}\text { promises to us, control over Hong } \\
\text { Kong }\end{array}$ \\
\hline Chinese Officials & ignored, pressured & $\begin{array}{l}\text { reporting obligations to the WHO, } \\
\text { the WHO }\end{array}$ \\
\hline Chinese Companies & the same rules \\
\hline
\end{tabular}

